\title{
RAMBUT INDAH DAN CANTIK DENGAN KOSMETIKA TRADISIONAL
}

\author{
Oleh \\ Made Diah Angendari \\ Jurusan Pendidikan Kesejahteraan Keluarga, FTK, UNDIKSHA
}

\begin{abstract}
ABSTRAK
Peranan rambut sangat penting untuk diperhatikan, karena rambut bukan hanya sebagai pelindung kepala dari berbagai hal seperti bahaya benturan/pukulan benda keras, sengatan sinar matahari, dan sebagainya, tetapi ia juga merupakan "perhiasan" yang berharga. Rambut yang tebal, panjang, hitam/berwarna, berkilau, sehat dan mudah diatur memberikan daya pesona tersendiri bagi pemiliknya. Keadaan kehidupan kita di alam tropis dengan udara panas, mengakibatkan banyak berkeringat dan banyaknya debu. Oleh karena itu teknik dan penggunaan kosmetika yang digunakan untuk perawatan kulit harus berfungsi untuk memelihara kesehatan kulit, mempertahankan kondisi kulit agar tetap baik dan mampu mencegah timbulnya kelainan pada kulit akibat proses usia, pengaruh lingkungan dan sinar matahari Perawatan rambut agar menjadi indah dan sehat dapat dilakukan dengan menggunakan kosmetika tradisional.
\end{abstract}

Kata-kata Kunci: Kosmetika Tradisional, Rambut, Indah

\begin{abstract}
The role of the hair is very important to note, because the hair is not only the chief patron of various things such as the danger of collision/punch hard objects, the sun, and so on, but it is also a "jewelry" valuable. The hair is thick, long, blac/ colored, shiny, healthy and easy to set up gives its owner the power to charm. The state of our life in the tropics with hot air, resulting in a lot of sweat and a large amount of dust. Therefore, the techniques used and the use of cosmetics for skin care should serve to maintain healthy skin, maintaining the skin in order to keep good condition and able to prevent the onset of skin disorder caused by the process of age, environmental influences and sunlight hair treatment to be beautiful and healthy can be done using traditional cosmetics.
\end{abstract}

Keywords: Traditional Cosmetics, Hair, Beautiful 


\section{PENDAHULUAN}

Rambut dikenal sejak zaman dahulu dengan julukan "mahkota" bagi wanita. Tetapi di zaman yang sudah maju seperti sekarang, julukan tersebut tidak lagi tertuju hanya kepada kaum wanita, namun juga untuk pria. Peranan rambut sangat penting untuk diperhatikan, karena rambut bukan hanya sebagai pelindung kepala dari berbagai hal seperti bahaya benturan/pukulan benda keras, sengatan sinar matahari, dan sebagainya, tetapi ia juga merupakan "perhiasan" yang berharga. Rambut yang tebal, panjang, hitam/berwarna, berkilau, sehat dan mudah diatur memberikan daya pesona tersendiri bagi pemiliknya. Tidak sedikit wanita ataupun pria yang menimbulkan rasa kagum hanya karena keindahan rambutnya.

Untuk memperoleh rambut yang tebal, hitam, sehat dan mudah diatur, rambut butuh perhatian. Satu hal yang perlu disadari adalah adanya berbagai faktor yang dapat mengakibatkan perubahan kondisi kulit kepala dan rambut seperti faktor usia lanjut, depresi, berkurangnya aktifitas kelenjar minyak dikulit kepala, gangguan pembuluh darah, gangguan hormon, pengaruh kosmetika, pajanan sinar matahari secara terus menerus dan kurangnya makanan yang bergizi untuk kepentingan pertumbuhan rambut. Apabila hal tersebut tidak diperhatikan maka akan memungkinkan terjadinya kerontokan rambut sehingga rambut menjaditipis bahkan botak, rambut rontok, kulit kepala dan rambut kering, rambut kusam dan sulit diatur serta timbulnya uban sebelum waktunya.

Salah satu usaha untuk menghindari hal tersebut maka perlu memperhatikandan mengindahkan hal perawatan kulit kepala dan rambut, dimana hal perawatan kulit kepala dan rambut sudah dikenal dan dilakukan sejak zaman nenek moyang kita.

Keadaan kehidupan kita dialam tropis dengan udara panas, mengakibatkan banyak berkeringat dan banyaknya debu. Oleh karena itu teknik dan penggunaan Kosmetika yang digunakan untuk perawatan kulit harus berfungsi untuk memelihara kesehatan kulit, mempertahankan kondisi kulit agar tetap baik dan mampu mencegah timbulnya kelainan pada kulit akibat proses usia, pengaruh lingkungan dan sinar matahari Perawatan kecantikan dapat dilakukan dengan menggunakan kosmetika tradisional. Pada hakekatnya perawatan secara tradisional merupakan 
salah satu manifestasi kebudayaan kita, dan sebagai seni perawatan diri yang turuntemurun.

\section{PEMBAHASAN}

\subsection{Pengertian Kosmetika}

Istilah kosmetika berasal dari kata Yunani yakni "Kosmetikos" yang berarti "Keahlian dalam menghias", itu pula sebabnya mungkin angkasa dinamakan cosmos, karena berhiasan bintang-bintang. Maka para ahli berpendapat bahwa definisi dari kosmetika itu pada dasarnya diseluruh dunia sama. Berdasarkan asal katanya definisi kosmetika ini sesuai pula dengan yang telah diputuskan oleh Menteri Kesehatan Republik Indonesia (1976:220) yakni; Kosmetika adalah bahan atau campuran bahan untuk digosokkan, dilekatkan, dituangkan, dipercikan atau disemprotkan pada, dimasukkan dalam, dipergunakan pada bahan atau bagian badan manusia dengan maksud membersihkan, memelihara, menambah daya tarik atau mengubah rupa dan tidak termasuk golongan obat. Sedangkan obat dirumuskan sebagai bahan, zat atau benda yang dipakai untuk diagnosis, pengobatan dan pencegahan suatu penyakit atau bahan, zat yang dapat mempengaruhi struktur dan faal tubuh. Sementara definisi kosmetika dalam peraturan Menteri Kesehatan RI No. 445/Menkes/Permenkes/1998 adalah sebagai berikut: "Kosmetika adalah sediaan atau paduan bahan yang siap untuk digunakan pada bagian luar badan (epidermis, rambut, kuku, bibir dan organ kelamin bagian luar), gigi dan rongga mulut untuk membersihkan, menambah daya tarik, mengubah penampakan, melindungi supaya tetap dalam keadaan baik, memperbaiki bau badan tetapi tidak dimaksudkan untuk mengobati atau menyembuhkan suatu penyakit".

Sedangkan kosmetika tradisional adalah kosmetika tradisional yang dapat dibuat sendiri, langsung dari bahan-bahan yang segar atau bahan-bahan yang telah dikeringkan, buah-buahan atau tanaman yang ada disekitar kita. Kosmetika ini diolah menurut resep dan cara pengolahan yang turun temurun dari nenek moyang misalnya; minyak kelapa dan minyak kemiri. Selain kosmetika-kosmetika yang murni di atas ada pula kosmetika tradisional ini yang sudah dicampur dengan bahanbahan kimia misalnya, bahan pengawet, sehingga kosmetika tersebut jadi tahan 
lama. Kesulitan yang dijumpai dalam memakai kosmetika tradisional ini ialah pemakainya yang kurang praktis karena membutuhkan waktu yang agak lama, sebab bila akan dipakai baru dibuat dan susah dalam penyimpanan sehingga tidak semua orang mau melakukannya sebagaimana halnya kosmetika modern. Tetapi kebaikan atau efek positifnya sangat memberi makna kepada pemakai karena secara umum kosmetika tradisional tidak memberikan pengaruh yang negatif kepada kulit kepala dan rambut.

\subsection{Tujuan, Fungsi dan Manfaat Kosmetika Rambut}

\section{a. Tujuan Penggunaan}

Secara umum baik teori maupun praktik tujuan penggunaan kosmetika rambut adalah untuk memelihara dan merawat kesehatan dan kecantikan kulit kepala dan rambut yang digunakan secara teratur. Hal ini bertalian erat dengan peraturan dan cara-cara produksi; penyimpanan dan penggunaan kosmetika rambut.

Sehubungan dengan itu, maka tujuan dari penggunaan kosmetika rambut dapat dikelompokkan sebagai berikut: 1) Melindungi kulit kepala dan rambut dari pengaruh-pengaruh luar yang merusak seperti: sinar matahari, polusi udara (debu, asap atau zat-zat kimia yang dikeluarkan pabrik, udara laut dan sebagainya), 2) Mencegah lapisan terluar kulit kepala dan rambut dari kekeringan, 3) Mencegah agar kulit kepala dan rambut tidak cepat kering, 4) Menjaga kulit kepala dan rambut tetap dalam kondisi normal, 5) Mengubah rupa atau penampilan.

\section{b. Fungsi Kosmetika}

Bahan-bahan yang terkandung di dalam suatu kosmetika mempunyai fungsi yang berbeda-beda. Hal ini dijelaskan juga oleh Tranggono dan Latifah (1992), dimana salah satunya fungsi adalah Emulgator yakni suatu bahan yang memungkinkan tercampurnya lemak/minyak dengan air menjadi suatu campuran yang homogen. Emulgator ini dikenal ada 2 macam emulsi yakni emulsi w/o (water oil) artinya jumlah minyak lebih banyak daripada air, contoh; mentega. Dan yang satu lagi disebut dengan o/w (oil water) artinya jumlah air lebih banyak daripada 
minyak, contoh; santan kelapa, bahan ini berfungsi untuk mengurangi kekeringan pada kulit kepala dan menyuburkan rambut.

\section{c. Manfaat Kosmetika Tradisional}

Manfaat yang dapat diperoleh antara lain: 1) Membersihkan kulit tubuh atau kulit kepala dan rambut 2) Memberikan ketahanan dan kerapian terhadap penataan rambut, 3) Menyuburkan rambut, 4) Menghindari beberapa gangguan kulit kepala dan rambut, 5) Memberikan kecemerlangan terhadap rambut.

\subsection{Jenis-jenis Kosmetika Tradisional}

Jenis-jenis kosmetika tradisioanal terdiri dari beberapa kelompok yakni sebagai berikut:

\section{a. Jenis kosmetika yang bersifat menyuburkan dan memperkuat akar rambut}

Beberapa jenis kosmetika rambut yang termasuk kelompok yang bersifat menyuburkan dan memperkuat akar rambut, adalah sebagai berikut:

1) Kelapa (Cocos nucifera L) Caranya ambil daging buah kelapa yang sudah cukup tua diparut dan dijadikan santan. Lalu dimasak tanpa memakai bahanbahan kimia. Tetapi agar minyak tersebut lebih memberikan aroma yang alami, sering orang menambah dengan rempah-rempah atau bunga-bungaan seperti: urat isa (akar dari tumbuh-tumbuhan yang menyerupai daun ilalang, banyak terdapat di daerah pegunungan), baunya sangat harum dan mengandung protein serta vitamin E yang baik. Kemudian ditambah dengan daun pandan wangi, bunga melati, bunga mawar dan sebagainya. Semua bahan tersebut dicuci bersih dengan air hangat dan dimasukkan ke dalam minyak yang sudah matang atau dalam keadaan hangat-hangat kuku, sehingga daun-daun tersebut tidak terlalu layu. Minyak inilah yang diuruturutkan ke kulit kepala sampai ke ujung rambut, terutama rambut yang kering dan pecah-pecah.

2) Kemiri (Aleurites moluccana ) Caranya adalah; dibutuhkan daging biji kemiri sebanyak $1 / 4 \mathrm{~kg}$, lalu itumbuk sampai halus. Kemudian dimasukkan ke dalam panci, tambahkan 1 gelas air bersih sambil diaduk sampai merata. 
Campuran tersebut lalu dipanaskan di atas api sampai mendidih dan keluar minyaknya. Setelah dingin lalu diperas dan disaring dengan sepotong kain, untuk diambil minyaknya, lalu didihkan kembali. Setelah dingin, minyak kamiri ini bisa digosokkan pada kulit kepala sambil ditekan-tekan dan rambut ditutup dengan cup rambut, biarkan lebih kurang 20 menit baru rambut dicuci bersih. Lakukan 2-3 kali seminggu.

3) Lidah buaya (L Aloe vera.) Cara pengolahannya adalah kulit daun lidah buaya dikupas. Ambil lendirnya yang menyerupai agar-agar lalu digosokkan ke seluruh kulit kepala dan rambut sampai basah. Tutup rambut kepala tersebut dengan sepotong kain. Sebaiknya dilakukan setelah mandi sore. Esok paginya baru rambut dicuci bersih. Lakukan setiap hari selama 3 bulan untuk mencapai hasil yang memuaskan.

4) Lidah mertua (Sansevieria Laurentii) Cara pengolahannya adalah; ambil 2 batang daun lidah mertua. lalu cuci bersih dan digiling halus. Tambahkan sedikit air, sambil diaduk rata seterusnya diperas dengan sepotong kain. Air perasan ini langsung digunakan untuk membasahi kulit kepala dan rambut. Tutup rambut dengan sepotong kain. Sebaiknya dilakukan sehabis mandi sore. Keesokan paginya rambut dicuci bersih.

5) Jarak pagar (Jatropha curcas L) Cara pengolahannya pilih biji jarak yang sudah tua, lalu ditumbuk sampai mengeluarkan minyak. Peras dengan sepotong kain. Minyaknya ini digunakan untuk membasahi kulit kepala sambil dipijat ringan. Biarkan beberapa saat lalu dicuci bersih dengan shampo. Lakukan seminggu sekali.

6) Pare (Momordica charantia L.) Cara pengolahannya daun pare yang masih segardicuci bersih tumbuk sampai menjadi adonan seperti bubur. Tambahkan $3 / 4$ cangkir air bersih. Ramuan ini kemudian diembunkan semalaman. Pagi hari disaring. Airnya dipakai untuk membasuh rambut dan kulit kepala.

7) Bayam (Amaranthus tricolor L.) Cara pengolahannya adalah; ambil seikat daun bayam segar lalu dicuci bersih kemudian ditumbuk sampai halus. Tambahkan garam halus seujung sendok teh, sambil diaduk rata. Peras dan 
saring. Selanjutnya air bayam yang telah disaring diminum sekaligus. Lakukan 2-3 kali seminggu.

8) Bandotan (Ageratum conyzoides L.) Cara pengolahannya adalah; ambil segenggam daun dan batang bandotan segar lalu dicuci bersih. Kemudian ditumbuk sampai lumat, seterusnya dioleskan ke seluruh kulit kepala dan rambut. Tutup kepala dengan sepotong kain. Biarkan selama 2-3 jam. Setelah itu rambut dibilas dengan air hangat dan dicuci sampai bersih. Lakukan 1-2 minggu sekali

9) Padi (Oryza sativa L.)

Caranya adalah; ambil dua ikat merang kemudian dibakar dalam panci atau bejana tanah liat sampai menjadi abu. Tambahkan 1 liter air, lalu diembunkan diudara terbuka selama 1 malam. Keesokan paginya, ambil airnya yang bening dan gunakan untuk mencuci rambut tanpa menggunakan shampo lagi. Selanjutnya rambut dibilas dengan air perasan jeruk purut yang telah dicampur dengan segelas air. Kemudian keringkan rambut secara alami sambil ditepuk-tepuk ringan dengan handuk.

10) Urang-aring (Eclipta prostrata L.)

Cara pengolahannya adalah; ambil segenggam urang-aring lalu cuci bersih dan ditumbuk sampai halus. Tambahkan 2 gelas air bersih, aduk rata diperas dan disaring. Air saringan ini diembunkan selama 1 malam. Selanjutnya digunakan untuk membasahi kulit kepala dan rambut sambil dipijat-pijat. Lakukan setiap hari sampai terlihat hasilnya.

11) Bahan-bahan berupa kecambah.

Cara pengolahannya adalah; ambil kira-kira $1 \frac{1}{2}$ ons kecambah lalu cuci bersih. Kecambah tersebut diremas-remas dengan menambahkan $1 / 4$ cangkir air bersih, kemudian disaring dan diusapkan ke kulit kepala serta rambut. Rambut dibungkus dengan handuk kecil selama 20 menit. Setelah itu rambut dicuci bersih dengan air hangat, dapat ditambahkan shampo, seterusnya rambut dibilas dengan air dingin sampai bersih.

12) Buah alpukat. Caranya adalah; ambil $1 / 2$ dari buah alpukat dan dihaluskan. Kemudian rambut dicuci dengan air hangat, seterusnya oleskan buah alpukat 
yang telah dihaluskan ke kulit kepala dan rambut. Lalu rambut dibungkus selama 15 menit. Setelah itu rambut dicuci dengan air hangat dan diakhiri dengan air dingin.

\section{b. Jenis Kosmetika yang Bersifat Mencegah/Anti Ketombe}

Jenis kosmetika yang sifatnya mencegah/anti ketombe dapat dikelompokkan sebagai berikut:

1) Inggu (Ruta angustifolia [L.] Pers.) yang disebut juga aruda (Melayu) atau godong minggu (Jawa). Cara pengolahannya adalah; ambil segenggam daun inggu segar, ditambah sepotong kunyit dan 1 sendok teh beras semuanya dicuci bersih lalu digiling atau ditumbuk halus sampai menjadi adonan seperti bubur. Ramuan ini digosokkan pada kulit kepala yang berketombe, lalu ditutup dengan sepotong kain. Sebaiknya dilakukan pada malam hari. Keesokan harinya rambut dicuci bersih. Lakukan setiap hari sampai sembuh.

2) Kangkung (Ipomoea aquatica Forsk.) Cara pengolahannya adalah; ambil batang kangkung yang masih segar dan bergetah kira-kira 1 ikat. Setelah dicuci bersih lalu dipotongpotong. Masukkan ke dalam panci/wadah, dan tambahkan air bersih sampai potongan batang kangkung terendam seluruhnya. Biarkan batang kangkung terendam selama 1 malam. Pagi harinya setelah rambut dicuci, ambil air rendaman batang kangkung dan gunakan untuk membasahi kulit kepala dan rambut sambil dipijat ringan.

Biarkan mengering secara alami. Setelah itu siang harinya rambut boleh dibilas dengan air bersih. Lakukan setiap hari sampai sembuh.

3) Jeruk nipis (Citrus aurantifolia Swingle.) Cara pengolahannya adalah; ambil 1 buah jeruk nipis, dipotong menjadi 2 atau 4 bagian. Gunakan untuk menggosok kulit kepala secara merata. Biarkan mengering beberapa saat. Kemudian kulit kepala dan rambut dibilas sampai bersih.

4) Mengkudu (Morinda citrifolia L.) Cara pemakaiannya adalah; ambil 3 buah mengkudu yang masak, lalu cuci dan diparut. Tambahkan sedikit air sambil diaduk rata, sehingga ia berbentuk bubur. Bubur mengkudu ini digosokkan ke seluruh kulit kepala. Biarkan sampai mengering baru dibilas dengan air 
sampai bersih. Lakukan 3 kali seminggu sampai rasa gatal dan ketombe menghilang.

5) Nanas (Ananas comosus [L.] Merr.) Cara mengolahnya adalah; ambil buah nanas yang telah masak sebanyak 1 buah. Kupas kulitnya lalu diparut. Hasil parutannya dipakai untuk menggosok kulit kepala yang bersisik dan mengelupas. Lakukan pada malam hari. Keesokan paginya rambut dicuci bersih. Cara ini dilakukan setiap malam sebelum tidur, hingga sembuh.

\section{c. Jenis Kosmetika yang Bersifat Mencegah Rambut Rontok/Botak}

Jenis kosmetika yang digunakan untuk mencegah rambut rontok dapat dikelompokkan sebagai berikut:

1) Asam (Tamarindus indica L.). Cara pengolahannya adalah; buah asam yang telah masak diambil daging buahnya. Tambahkan sedikit air bersih sambil diremas-remas. Lalu saring dengan sepotong kain. Gosokkan sari buah asam tersebut ke seluruh kulit kepala sambil dipijat ringan (massage). Biarkan beberapa saat, kemudian rambut dicuci bersih dengan shampoo

2) Bunga kembang sepatu (Hibiscus rosa-sinensis L.) Cara menggunakannya adalah; ambil segenggam daun bunga sepatu yang berbunga putih. Cuci bersih lalu digiling sampai halus. Tambahkan 1 cangkir air bersih sambil diremas-remas. Kemudian peras dan saring. Air perasannya digunakan untuk membasahi kulit kepala dan rambut sambil dipijat ringan. Biarkan meresap selama 1 jam, baru rambut dibilas dengan air bersih. Lakukan setiap hari sampai terlihat hasilnya.

3) Lobak (Raphanus sativus L.) Caranya pemakaiannya adalah; Akar lobak segar ukuran sedang dicuci lalu diparut. Air perasannya digunakan untuk membasahi kulit kepala yang botak sambil dipijat ringan. Lakukan setiap hari sampai tampak hasilnya.

4) Mangkokan (Nothopanax scutellarium) Cara pengolahannya adalah; ambil daun yang tua dan segar sebanyak 5-10 lembar dicuci bersih lalu digiling halus. Tambahkan sedikit minyak kelapa sambil diaduk sampai menjadi adonan seperti bubur. Saring dan peras. Hasil perasan tersebut dioleskan 
pada kulit kepala sambil dipijat ringan. Setelah merata, tutup kepala dengan handuk sampai terasa adanya hawa panas yang timbulkannya, karena ia akan berfungsi melembapkan kulit kepala dan rambut. Biarkan selama 1 jam baru rambut dicuci dengan air hangat, selajutnya rambut dicuci dengan air dingin sampai bersih. Lakukan 2-3 kali dalam seminggu.

5) Pandan wangi (Pandanus amaryllifolius Roxb.) Cara pemakaiannya adalah; ambil 10 lembar daun waru muda, segenggam daun urang-aring, 5 lembar daun mangkokan, 1 lembar daun pandan, 10 kuntum bunga melati dan 1 kuntum bunga mawar semuanya dicuci bersih lalu dipotong-potong secukupnya. Tambahkan minyak wijen, minyak kelapa dan minyak kemiri masing-masing $1 / 2$ cangkir lalu dipanaskan sampai mendidih. Setelah dingin disaring, lalu dioleskan ke seluruh kulit kepala sambil dipijat ringan. Lakukan malam hari sebelum tidur. Esok paginya rambut dicuci bersih. Lakukan 2-3 kali dalam seminggu.

6) Pisang (Musa paradisiaca L) Cara pemakaiannya adalah; ambil bonggol pisang secukupnya lalu dicincang atau diparut dan diperas untuk diambil cairannya. Cairannya digunakan untuk membasahi kulit kepala dan rambut sambil dipijat ringan. Lakukan setiap pagi. Kepala terasa sejuk dan rambut akan tumbuh dengan subur. Bonggol dari semua jenis pisang dapat digunakan, kecuali bonggol pisang susu.

7) Semangka (Citrullus vulgaris Schrad.) Cara penggunaannya adalah; ambil bagian dari kulit semangka yang berwarna putih. Gosok-gosokkan pada kulit kepala secara merata. Lakukan pada sore hari dan dibiarkan selama 1 malam supaya meresap pada kulit kepala. Keesokan paginya rambut dicuci sampai bersih. Lakukan 1-2 kali dalam seminggu.

\section{d. Jenis Kosmetika yang Bersifat Mencegah/Anti Uban}

Jenis kosmetika yang sifatnya mencegah/anti uban dapat dikelompokkan sebagai berikut: 
1) Pepaya (Carica papaya L) Cara pemakaiannya adalah; ambil biji buah pepaya yang telah kering sebanyak 30 butir lalu disangrai, kemudian ditumbuk sampai halus. Tambahkan 1 sendok minyak kelapa sambil diaduk rata. Campuran ini digunakan untuk menggosok kulit kepala yang beruban. Biarkan selama 1 malam. Keesokan harinya rambut dicuci bersih. Lakukan setiap hari sampai tampak hasilnya.

2) Rambutan (Nephelium lappaceum L.) Cara penggunaannya adalah; ambil daun rambutan secukupnya dan dicuci bersih lalu ditumbuk sampai halus. Tambahkan sedikit air sambil diaduk rata sampai menjadi adonan seperti bubur encer. Peras dan saring dengan sepotong kain. Air yang terkumpul digunakan untuk membasahi kulit kepala dan rambut. Lakukan setiap hari sampai terlihat hasilnya.

\section{PENUTUP}

Kesulitan yang dijumpai dalam memakai kosmetika tradisional ini ialah pemakainya yang kurang praktis karena membutuhkan waktu yang agak lama, sebab bila akan dipakai baru dibuat dan susah dalam penyimpanan sehingga tidak semua orang mau melakukannya sebagaimana halnya kosmetika modern. Tetapi kebaikan atau efek positifnya sangat memberi makna kepada pemakai karena secara umum kosmetika tradisional tidak memberikan pengaruh yang negatif kepada kulit kepala dan rambut.

\section{DAFTAR PUSTAKA}

Kusumadewi. 2003. Rambut Anda, Masalah, Perawatan Dan Penataannya. Jakarta. Gramedia Pustaka Utama.

Rostamailis, dkk. 2009. Tata Kecantikan Rambut. Direktorat Pembinaan Sekolah Menengah Kejuruan. Depdiknas.

Rostamailis. 2005. Perawatan Badan, Kulit dan Rambut. Jakarta. Rineka Cipta.

Kusantati Herni, dkk. 2009. Tata Kecantikan Kulit. Direktorat Pembinaan Sekolah Menengah Kejuruan. Depdiknas. 
Tranggono, Retno IS. 1992. Kiat Apik Menjadi Sehat Dan Cantik. Jakarta. PT Gramedia Pustaka Utama.

JPTK, UNDIKSHA, Vol. 9, No. 1, Januari $2012: 25$ - 36 